\title{
The use of cardiac MRI in a rare case of primary mural endocarditis
}

\author{
Mayur Patel, Zeshan Ahmad, Edward Distler, Brenen Swofford
}

\begin{abstract}
- Additional material is published online only. To view, please visit the journal online (http://dx.doi.org/10.1136 bcr-2017-221607).
\end{abstract}

Internal Medicine, University of Arizona College of Medicine Phoenix, Phoenix, Arizona, USA

\section{Correspondence to Dr Mayur Patel, \\ mppatel88@gmail.com}

Accepted 2 August 2017

\section{e \\ CrossMark}

To cite: Patel M, Ahmad Z, Distler E, et al. BMJ Case Rep Published Online First: [please include Day Month Year]. doi:10.1136/bcr-2017 221607

\section{DESCRIPTION}

A 47-year-old-man with a history of intravenous drug use and recent diagnosis of T-cell lymphoma returned to the emergency department 1 week after initiation of chemotherapy with complaint of left olecranon swelling. Admission vital signs included body temperature of $36.6^{\circ} \mathrm{C}$, blood pressure $108 / 65$, heart rate 76 and respiratory rate 18 . Physical examination of the left olecranon revealed that it was warm and indurated. An X-ray of the left olecranon and aspiration of the swelling confirmed bursitis. Both the aspiration culture and blood cultures demonstrated methicillin-resistant Staphylococcus aureus. A transthoracic echocardiogram was subsequently performed revealing a large echodensity in the left ventricular apex (figure 1 ; see online supplementary video 1 and supplementary video 2 ). The patient refused to undergo a transoesophageal echocardiogram due to its invasive approach. Therefore, a cardiac MRI (CMRI) was obtained to evaluate the lesion. The CMRI demonstrated left ventricular ejection fraction $65 \%$, no valvular vegetations and two linear densities in the left ventricular apex (figure 2). An MRI brain did not reveal any thromboembolic phenomenon. The patient was discharged on intravenous ceftaroline for 6 weeks with follow-up transthoracic echocardiogram after completion of therapy, which demonstrated no intracardiac masses (figure 3; see online supplementary video 3 and supplementary video 4 ).

Primary mural endocarditis is a rare, non-valvular form of endocarditis due to disruption of the endothelial lining of the cardiac chambers. ${ }^{1}$ Non-valvular endocardial infections are often secondary to valvular vegetations, regurgitation, prosthetic valves and congenital shunts; however, primary mural endocarditis occurs without any cardiac structural abnormalities. ${ }^{2}$ Tahara et al performed a Medline literature search and reported only 19 cases of primary mural endocarditis since 1986. ${ }^{2}$ Transthoracic and transoesophageal echocardiograms remain the standard of care for prompt diagnosis of this disease process. ${ }^{2}$
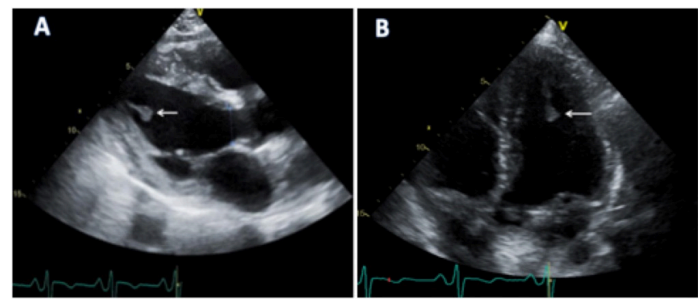

Figure 1 Transthoracic echocardiogram in a parasternal long view $(A)$ and apical four chamber view (B) demonstrating a large echodensity in the left ventricular apex (arrows).

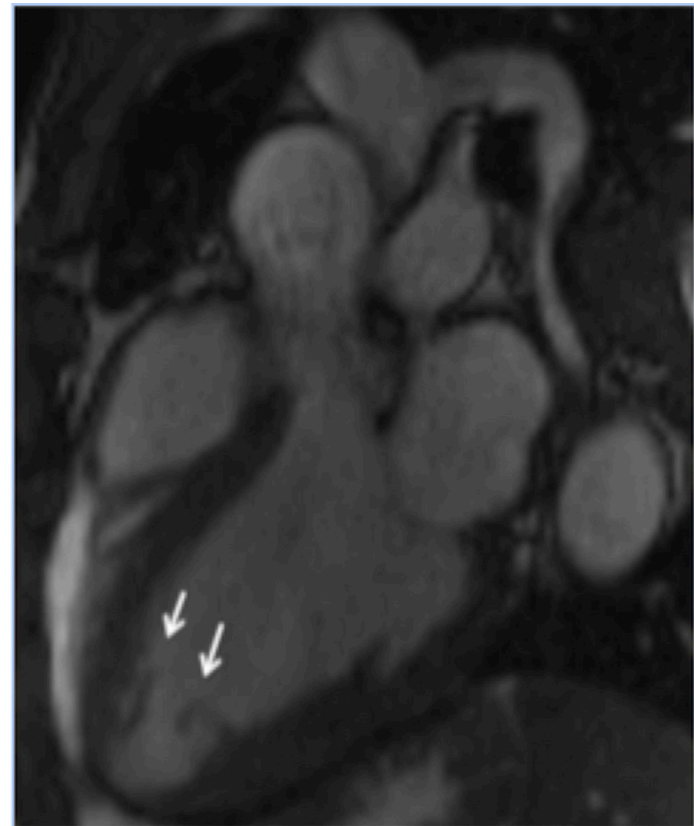

Figure 2 Cardiac MRI in coronal view demonstrating two linear densities in the left ventricular apex. The first measuring $1.6 \times 0.3 \mathrm{~cm}$ that is mobile (left arrow) and the second measuring $0.5 \times 0.3 \mathrm{~cm}$ (right arrow) that is not mobile. There were no valvular vegetations noted.

Yet, patients commonly opt against transoesophageal echocardiogram due to invasive approach or sedation requirements. In these cases, CMRI maybe an adequate alternative option for detailed evaluation of cardiac structures. A few low-powered studies have suggested that CMRI is effective at detection of valvular vegetations. ${ }^{3}$ In addition, the detection of endothelial inflammation on CMRI through delayed enhancement can contribute to diagnosis of non-valvular endocarditis. ${ }^{3}$ Further randomised, large-scaled studies are required to validate these correlations.
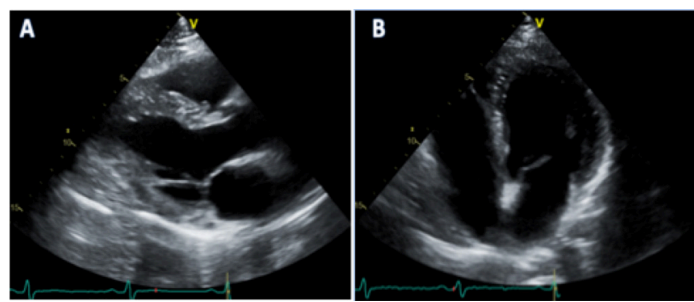

Figure 3 Transthoracic echocardiogram performed after 6 weeks of intravenous antibiotics in a parasternal long view (A) and apical four chamber view (B) revealing no intracardiac mass present compared with previous imaging. 


\section{Learning points}

- Primary mural endocarditis is a rare infection involving non-valvular endocardium due to inflammation and disruption of the endothelial lining of the cardiac chambers without any other cardiac structural abnormalities. ${ }^{1}$

- Risk factors for primary mural endocarditis include immunocompromised state, intravenous drug use and recent surgery. The most common pathogens involved include Staphylococcus aureus, Candida, Streptococcus and Aspergillus. ${ }^{12}$

- Though transthoracic and transoesophageal echocardiogram remains the gold standard, initial studies suggest CMRI can be effective as an alternative method to evaluate valvular and non-valvular endocarditis. ${ }^{3}$
Contributors MP, ZA: involved in diagnosis, patient management, manuscript preparation, literature review. ED, BS: involved in literature review and critical review of manuscript.

Competing interests None declared.

Patient consent Obtained.

Provenance and peer review Not commissioned; externally peer reviewed.

(C) BMJ Publishing Group Ltd (unless otherwise stated in the text of the article) 2017. All rights reserved. No commercial use is permitted unless otherwise expressly granted.

\section{REFERENCES}

1 Kearney RA, Eisen HJ, Wolf JE. Nonvalvular infections of the cardiovascular system. Ann Intern Med 1994;121:219-30.

2 Tahara M, Nagai T, Takase Y, et al. Primary mural endocarditis without valvular involvement. J Ultrasound Med 2017;36:659-64.

3 Dursun M, Y.lmaz S, Yllmaz E, et al. The utility of cardiac MRI in diagnosis of infective endocarditis: preliminary results. Diagn Interv Radiol 2015;21:28-33.

Copyright 2017 BMJ Publishing Group. All rights reserved. For permission to reuse any of this content visit

http://group.bmj.com/group/rights-licensing/permissions.

BMJ Case Report Fellows may re-use this article for personal use and teaching without any further permission.

Become a Fellow of BMJ Case Reports today and you can:

- Submit as many cases as you like

- Enjoy fast sympathetic peer review and rapid publication of accepted articles

- Access all the published articles

- Re-use any of the published material for personal use and teaching without further permission

For information on Institutional Fellowships contact consortiasales@bmjgroup.com

Visit casereports.bmj.com for more articles like this and to become a Fellow 